\title{
Autoimmunity and Inflammation in Myelodysplastic Syndromes
}

\author{
Ofir Wolach Richard Stone \\ Department of Medical Oncology, Dana-Farber Cancer Institute, Boston, Mass., USA
}

\section{Key Words}

Autoimmune and inflammatory conditions · Connective tissue diseases $\cdot$ Myelodysplastic syndrome

\begin{abstract}
Autoimmune and inflammatory conditions (AICs) are encountered in up to $25 \%$ of patients with myelodysplastic syndromes (MDS). A wide range of AICs have been reported in association with MDS and can range from limited clinical manifestations to systemic diseases affecting multiple organs. Vasculitides, connective tissue diseases, and inflammatory arthritis are frequently reported in different studies; noninfectious fever and constitutional symptoms at presentation are common. Associations between AICs and specific MDS characteristics vary by study, but the available data suggest that AICs cluster more often in younger patients with higher-risk MDS. In general, AICs do not seem to confer worse survival, although certain AICs may be associated with adverse outcome (e.g. vasculitis) or progression of MDS (Sweet's syndrome). Nonetheless, these complications may have a significant impact on quality of life and affect the timing and type of MDS-directed therapy. The mainstay of management of these complications in the short term relies on immunosuppressive drugs. Increasing evidence suggests that hypomethylating agents may be effective in treating these complications and reduce steroid dependence. While the pathogenesis of AICs is incompletely understood, grow-
\end{abstract}

ing appreciation of cellular immune deregulation, cytokine hypersecretion, and the genetic heterogeneity underlying MDS may improve our understanding of common pathways linking MDS, inflammation, and autoimmunity.

(c) 2016 S. Karger AG, Basel

\section{Introduction}

The myelodysplastic syndromes (MDS) are a heterogeneous group of clonal stem-cell disorders characterized by ineffective hematopoiesis, abnormal cellular morphology, and a propensity for progression to acute leukemia. MDS is regarded as the most prevalent form of acquired bone marrow failure syndrome in adults (estimated at $60,000-120,000$ cases per year in the US) and is most frequently encountered in the older population [1].

Although most of the symptom burden in MDS stems from marrow failure and its associated cytopenias, it is not uncommon for patients with MDS to present with autoimmune and inflammatory conditions (AICs).

AICs can appear before, during, or after the diagnosis of MDS. Observational studies suggest that chronic immune stimulation can promote the development of myeloid malignancies [2-4]. For example, Anderson et al. [2] studied more than 13,000 patients over the age of 67 years with myeloid malignancies reported to the Surveillance, Epidemiology and End Results (SEER) registry and

\section{KARGER}

E-Mail karger@karger.com www.karger.com/aha
C 2016 S. Karger AG, Basel

0001-5792/16/1362-0108\$39.50/0
Ofir Wolach

Department of Medical Oncology, Dana-Farber Cancer Institute 450 Brookline Ave., Boston, MA 02115 (USA)

E-Mail Ofir_wolaj@dfci.harvard.edu 
compared them to $>160,000$ population-based controls. Preexisting AICs correlated with an increased risk for a variety of myeloid diseases. Odds ratios (ORs) for developing acute myeloid leukemia and MDS were 1.29 (95\% CI: $1.20-1.39)$ and 1.5 (95\% CI: 1.35-1.66), respectively. Importantly, at least 1 year of latency from diagnosis of an AIC to the development of a myeloid malignancy was required in this analysis in order to reduce the chance for reverse causality (i.e. MDS leading to autoimmune disease). However, the proportion of patients treated for their underlying AIC with immunosuppressive therapies (ISTs) was not reported in this trial. In patients whose AIC is treated with IST, it is difficult to discern which potential predisposing factor is most important in the development of MDS because drugs like azathioprine and cyclophosphamide can potentially lead to secondary MDS [5-7].

It is not unusual for a patient with MDS and without a long-standing history of a rheumatological disorder to present with an autoimmune or inflammatory complication during the diagnosis or progression of MDS. The interval between the onset of MDS and the associated AIC tends to be short. For example, in a recent report on 123 patients with MDS or chronic myelomonocytic leukemia (CMML) and systemic AICs, the median interval between the diagnoses of the 2 conditions was 8.4 months. One third of the patients had their AIC diagnosed at the same time as their MDS while another third of the patients were diagnosed before or after MDS diagnosis, respectively [8]. This finding is similar to previous reports that noted short latency between the onset of myeloid and rheumatological disorders $[5,9]$.

The temporal association between MDS and AICs may suggest common pathogenic pathways. Increasing appreciation of immunologic dysregulation in MDS and new insights into the impact of somatic genetic alterations and the associated clonal hematopoiesis in MDS on disease biology and phenotype may provide novel explanations for the co-occurrence of MDS and AICs.

In this review we will discuss the epidemiology, pathogenesis, and clinical presentation of MDS-associated AICs.

\section{The Spectrum of Systemic AICs in MDS}

A wide range of AICs were reported to be associated with MDS and can range from limited clinical manifestations such as autoimmune hemolytic anemia to systemic diseases affecting multiple organs such as systemic vascu- litides, polyarthritis, and connective tissue diseases (CTDs).

Collectively, the incidence of this association has been reported in several retrospective analyses to be in the range of $7-25 \%$ of MDS patients [10]. However, these studies differ in their definition of MDS and vary in their definition for MDS-associated AICs (table 1). In one of the first systematic evaluations of AICs in MDS, Enright et al. [5] retrospectively analyzed 221 MDS patients (diagnosed on the basis of the French-American-British criteria). Thirty patients (14\%) were found to have autoimmune conditions. Systemic vasculitis was the most frequent diagnosis (18 of 30 patients, predominantly involving the skin), followed by isolated autoimmune manifestations in 11 patients, including skin vasculitis, polyneuropathy, or glomerulonephritis; CTDs were noted in 5 patients. Immunologic laboratory abnormalities were found in 40 of the 221 patients $(18 \%$; 10 patients without clinical AICs), with antinuclear antibodies being the most prevalent finding $(\mathrm{n}=14)$ followed by hypergammaglobulinemia $(\mathrm{n}=9)$.

One systematic review summarized data from 10 retrospective studies dating from the early 1990s to 2009 and found vasculitides (isolated or systemic) to be the most frequent diagnosis in patients with MDS and an associated AIC (40\%), followed by seronegative arthritis (27\%), neurologic disease $(24 \%)$, bronchiolitis obliterans with organizing pneumonia/interstitial pulmonary fibrosis (15\%), glomerulonephritis (12\%), rheumatoid arthritis (12\%), and Sweet's syndrome (10\%) [10].

Fain et al. [11] studied 60 patients with cancer-associated vasculitis and reported that MDS was the most common neoplasia associated with vasculitis. Leukocytoclastic vasculitis and PAN were the most frequent types of vasculitis (43\% of cases each). MDS-associated vasculitides followed a more aggressive course as compared to patients with other malignancies. Patients with MDS more frequently had renal manifestations $(p=0.02)$, steroid dependence $(p=0.04)$, and lower remission rates from their vasculitis $(\mathrm{p}=0.04)$.

A recent study from France included information on 123 patients with MDS or CMML and associated systemic AICs collected from 25 centers [8]. The median age for this cohort was 74 years and two thirds of the patients were males; the most common WHO 2008 diagnoses in this cohort were refractory cytopenia with multilineage dysplasia (26\%), refractory anemia with excess blasts 1 (15\%), and CMML-1 (in 16\%); most patients (72\%) had low or intermediate-1 risk according to the International Prognostic Scoring System (IPSS). The most common 


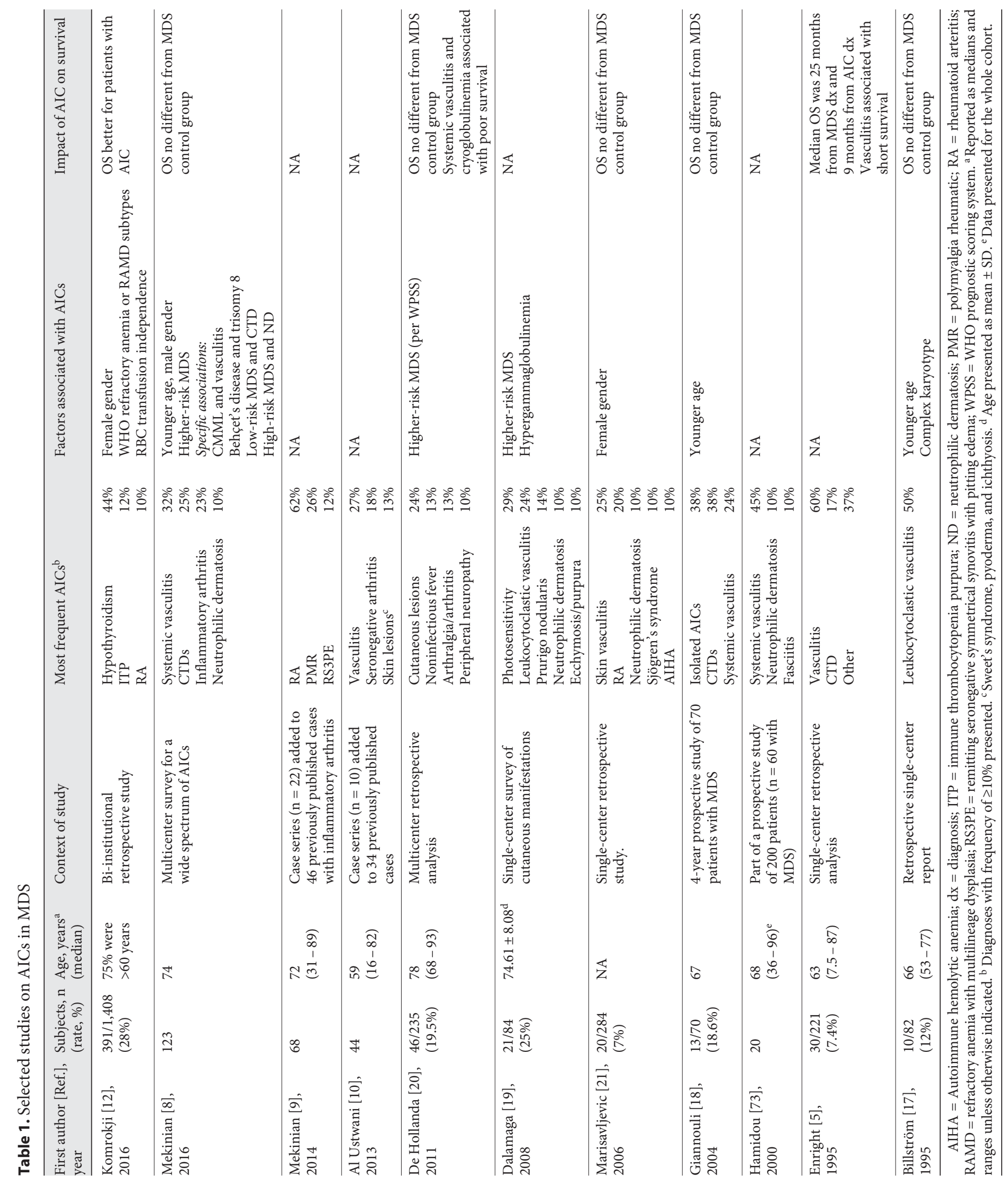


systemic AICs in this cohort were systemic vasculitides (32\%), CTDs (25\%), inflammatory arthritis (23\%), neutrophilic disease (10\%), and unclassified syndromes (11\%). Noninfectious fever with constitutional symptoms was part of the clinical presentation in 35\% of patients and a mean of 2.6 organs were involved per case. The most frequent organs involved at presentation were joints (70\%); skin (55\%); ear, nose or throat (27\%); lung (17\%); eyes (16\%); peripheral nerves (12\%), and the kidney $(10 \%)$.

Komrokji et al. [12] retrospectively reviewed the characteristics of 1,408 patients from 2 large institutions in the US and UK and reported that 391 (28\%) had an AIC. Hypothyroidism (in 44\%) and immune thrombocytopenia purpura (in 12\%) were the most prevalent AICs. The higher frequency of AICs seems to be related to the more inclusive definition of AICs used in this study.

Taken together, the available data suggests a wide spectrum of AICs (table 1). Vasculitides, CTDs, and inflammatory arthritis are frequently reported. However, there are numerous case reports and series describing rare associations of MDS and uncommon AICs.

The joints and skin seem to be the most frequently involved, and noninfectious fever is common at presentation. However, organ dysfunction in MDS cannot be assumed to be due to AICs. For example, while skin abnormalities may be a manifestation of AICs, they can also represent a drug-reaction or neoplastic infiltration (extramedullary disease). This underscores the importance of obtaining histology whenever possible for diagnosis.

Lastly, laboratory abnormalities such as hypergammaglobulinemia and positive autoimmune serologies (antinuclear antibodies, rheumatoid arthritis, positive DAT, etc.) can be found even in the absence of an overt clinical syndrome. The predictive and prognostic significance of such 'subclinical' findings remains uncertain.

\section{Does Autoimmunity Correlate with Specific Clinical Characteristics or Outcome?}

Mekinian et al. [8] compared 123 MDS patients with AICs to 665 MDS controls. Patients with AICs were more likely to be younger $(p<0.01)$, male $(p=0.03)$, and to have higher-risk features such as poor karyotype (16\% vs. $11 \%$, $\mathrm{p}=0.04)$ and a high-risk IPSS. Patients with AICs were less likely to have refractory anemia with ring sideroblasts $(\mathrm{p}<0.01)$. Specific correlations were found in this study between CMML-1 and the presence of vasculitis and between trisomy 8 and a Behçet-like syndrome. These cor-

Autoimmunity and Inflammation in MDS relations were previously observed [13-15]. Subgroup analysis suggested that CTDs were associated with lowerrisk disease while neutrophilic dermatosis was more frequent in patients with high-risk MDS. The association of neutrophilic dermatosis with disease progression and leukemic transformation was previously reported [16].

Several other studies have also found AICs to be associated with younger age $[17,18]$, high-risk disease features $[17,19,20]$, and hypergammaglobulinemia [19]. Female gender correlated with AICs in some reports $[12,21]$.

The effect of AICs on the outcome of patients with MDS was addressed in several studies. Enright et al. [5] reported that patients with MDS and an associated autoimmune condition $(n=30)$ had a median survival of 25 months from MDS diagnosis, but only 9 months from the diagnosis of the associated autoimmune disease. Okamoto et al. [22] compared the outcome of 19 patients with MDS and an AIC to 153 patients with MDS without autoimmunity, and demonstrated that outcome was inferior for those patients with an AIC; a CD4/CD8 ratio >1 predicted better outcome in that study. Systemic vasculitis was shown to predict poor outcome in some studies $[5$, $11,13,20]$ although other studies failed to show a difference in outcome based on the specific AIC [8].

More recent studies have failed to demonstrate the adverse impact of AICs on patient outcome $[8,18,20,21]$, potentially reflecting differences in study design, statistical methods, and advances in therapy of both MDS and AICs. One hundred and twenty-three patients with MDS and an associated AIC were compared to 665 patients without such a complication. No difference in survival was demonstrated when comparing the outcomes of both cohorts; outcome in patients with MDS and AICs and MDS controls remained similar even after matching patients for analysis based on gender and IPSS risk [8]. However, a recent study reported better outcomes for patients with AICs as compared to MDS controls. A median overall survival (OS) of 60 months for 293 patients with MDS and AICs compared favorably with 45 months in 1,017 MDS patients without AICs $(\mathrm{p}=0.006)$, probably reflecting the higher transformation rate to leukemia in the latter group ( 30 vs. $23 \%$; $\mathrm{p}=0.011$ ). The survival advantage for patients with AIC was maintained in a multivariate analysis adjusting for R-IPSS and age $>60$ years (HR 0.78; $95 \%$ CI: 0.66-0.92). The better outcome for the AIC patients in this study is contradictory to all other published studies and may be related to the differences in patient selection (e.g. almost half of the AIC cohort in this study was selected based on diagnosis of hypothyroidism) [12].

Acta Haematol 2016;136:108-117 


\section{How to Treat AICs in MDS}

Treating AICs can be challenging in the setting of MDS. The side effects of drugs traditionally used to treat these diseases can pose special problems in patients with an already increased risk for infection and a limited marrow reserve.

Mekinian et al. [8] reported in their multicenter study that 118 of the 123 patients with MDS and AICs (96\%) were treated with IST. Ninety-one percent of the treated patients received steroids; $23 \%$ of these received steroids in combination with an additional AIC-directed drug, most frequently hydroxychloroquine, methotrexate, biologics, cyclophosphamide, and thalidomide. Therapy with steroids \pm additional agents resulted in a complete or partial response of the AICs in 52 and $31 \%$ of cases, respectively. Second- and third-line therapies for noncomplete responders usually included steroids in combination with an additional IST drug and resulted in one third of the patients having complete responses and one third experiencing partial responses. Overall, 59\% of the patients achieved remission from their AIC and 21\% remained steroid dependent. At least one significant infectious complication requiring admission was recorded in $67 \%$ of the patients, pointing to the possible implications of IST in the context of MDS. The response to IST was independent of the timing of AIC or inflammatory diagnosis (before, concurrent, or after MDS diagnosis) and was also independent of MDS disease status (similar remission rates of the AIC for stable and progressive MDS).

Previous smaller studies also demonstrated the efficacy of steroids (alone or in combination) in achieving an initial prompt response of AICs, but limited durability of such a response and the occurrence of opportunistic infections were also reported in these studies $[5,8,17,18$, 23].

Conventional wisdom and experience from other tumors associated with paraneoplastic syndromes suggest that targeting the underlying malignancy can effectively treat paraneoplastic complications [24]. Therapies used to treat MDS such as hypomethylating agents (HMAs) or lenalidomide may treat AICs by reducing the disease burden and mitigating the expression of neoplasia-related inflammatory drivers or by directly affecting the AIC.

Several anecdotal case series report on the efficacy of HMAs in treating AICs associated with MDS $[25,26]$. Pilorge et al. [25] reported dramatic responses to HMAs in 3 patients with MDS whose autoimmune manifestations were refractory to multiple lines of IST. Additional reports have demonstrated that HMAs in combination with steroids or other ISTs seem to be associated with high response rates of the associated AIC [23]. In one case report, a 44-year-old male with MDS and an associated SLE-like syndrome had a dramatic response to HMAs that was accompanied by a significant decrease in the patient's T-regulatory cell $\left(\mathrm{T}_{\text {reg }}\right)$ population, suggesting an effect of this intervention on T-cell dynamics [27]. Mekinian et al. [8] reported that the administration of azacitidine to 11 patients with MDS and AICs was associated with response of the AIC in 80 and $55 \%$ of patients at 3 and 6 months, respectively. The use of azacitidine in this study was associated with a significant reduction in the administered steroid dose (by approximately $50 \%$ ).

Fraison et al. [28] recently reported on the characteristics and outcomes of 22 patients with MDS and an associated AIC treated with azacitidine. Half of the patients had IPSS int- 1 disease and the other half were int- 2 risk at the time of azacitidine therapy; over $90 \%$ of patients were receiving steroids at the time of HMA initiation. After a median of 3 cycles of therapy, $73 \%$ of the patients $(\mathrm{n}=16)$ achieved complete remission of their AIC and $14 \%$ had a partial remission. Therapy was associated with a significant reduction in steroid dose in steroid-dependent or steroid-resistant patients (median prednisone dose reduced from 50 to $5 \mathrm{mg} /$ day; $\mathrm{p}=0.01$ ); one third of the patients were able to discontinue steroids.

Very limited information is available to date on the effect of lenalidomide or allogeneic transplantation in this setting [10].

In summary, the available data suggest that the use of steroids and other ISTs is best utilized for short-term control of AICs associated with MDS, but many patients will require additional therapy due to recurrence of their AIC or steroid-dependence. Chronic therapy with these agents should always be balanced by the risk of severe infections and worsening cytopenias, and should thus be avoided if possible. MDS-directed therapy, specifically HMAs, can be efficacious in controlling AIC symptoms and reducing steroid doses.

\section{MDS, Inflammation, and Autoimmunity - Putting the Puzzle Together}

The development and progression of MDS is associated with the acquisition of genetic alterations. Several studies have described the genetic landscape of MDS and correlated specific genetic alterations with prognosis and disease phenotype [29-31]. 
The contribution of immune dysregulation in MDS to bone marrow failure and disease progression is increasingly being appreciated. Many of the immunologic perturbations in MDS can also promote autoimmunity and inflammation. A subset of patients with MDS respond to IST, suggesting that the immune system plays a role in the pathogenesis of MDS, at least some cases [32, 33]. Younger age, lower-risk disease, hypocellular marrow, shorter duration of transfusion dependence, and HLA-DR15 positivity were all previously reported to predict response to IST.

Several alterations in the innate and adaptive immune systems have been described in MDS patients.

A relatively limited T-cell receptor repertoire, especially within the CD8+ compartment, is characteristic $[34,35]$. Oligoclonal or monoclonal T-cell expansions of CD8+/CD57+/CD28 - effector cells were found in up to $50 \%$ of MDS patients as compared to $5 \%$ of healthy controls, pointing towards an autoimmune, antigen-driven response in these patients [36]. Additionally, T cells were suggested to derive from the malignant stem-cell clone in some cases, thus providing an alternative explanation for T-cell clonality in MDS [37].

Baumann et al. [38] demonstrated that depleting $\mathrm{T}$ cells from primary MDS samples restores normal hematopoiesis in long-term bone marrow cultures, and proposed that autologous lymphocytes suppress normal hematopoiesis in MDS.

Deficiency in human telomerase reverse transcriptase results in increased telomere attrition in T cells from patients with MDS as compared to controls. Senescent T cells tend to hypersecrete a variety of inflammatory cytokines that can contribute to the disease phenotype [39].

Specific T-cell subpopulations have been shown to be altered in number and function in MDS. CD4+ $\mathrm{CD} 25+\mathrm{FOXP} 3+\mathrm{T}_{\text {regs }}$ are believed to suppress autoreactivity. Decreased number or function of $\mathrm{T}_{\text {regs }}$ is associated with autoimmunity. On the other hand, increased $\mathrm{T}_{\text {reg }}$ activity can promote tumorigenesis through loss of immunosurveillance [40]. In MDS, patients with advanced disease demonstrate increased $\mathrm{T}_{\text {regs }}$ that correlate with poor outcome, while lower-risk patients have decreased $\mathrm{T}_{\text {regs }}$ [41-45]. Furthermore, low-marrow $\mathrm{T}_{\text {regs }}$ are associated with both an increase in the CD8+ T-cell compartment in the marrow [41] and recruitment of proinflammatory IL-17-producing T-helper cells (TH17) [46]. However, the clinical relevance of these observations to AICs in MDS is not clear since clinical observations (as noted above) suggest that AICs cluster more often in patients with higher-risk MDS.

Autoimmunity and Inflammation in MDS
Treatment with HMAs may impact T-cell dynamics in MDS. Azacitidine was shown to decrease $\mathrm{T}_{\text {reg }}$ number and function in patients with MDS [47]. Additionally, azacitidine therapy was associated with an increase in Tcell receptor diversity, suggesting a role for HMAs in reverting some of the immune dysregulation associated with MDS progression [48].

Several additional immune cell populations such as macrophages and natural killer cells have been shown to increase in number and activity in the marrow of patients with low-risk MDS and to decrease as MDS progresses [49]. While perturbations in the B-cell compartment are less studied, B-cell progenitors may be reduced in lowrisk MDS [50].

Recently, immature myeloid-derived suppressor cells were shown to accumulate in the marrow of patients with MDS. These cells expand in response to proinflammatory signals and contribute to the development of cytological dysplasia and cytopenias by driving the overproduction of various suppressive cytokines (e.g. TGF- $\beta$, IL-10) [51]. Interestingly, chronic immune stimulation that was implicated in the pathogenesis of MDS [3] promotes the accumulation of myeloid-derived suppressor cells [52].

An increase in the secretion of various inflammatory cytokines is frequently observed in MDS and is linked to various aspects of disease phenotype [53]. Many of these cytokines are also implicated in the pathogenesis of AICs [54]. IL- 6 and TNF- $\alpha$ negatively affect hematopoiesis and promote fas-mediated apoptosis of CD34+ marrow cells $[55,56]$. Infliximab, a monoclonal anti-TNF- $\alpha$ antibody demonstrated some activity in early-phase clinical trials of low-risk MDS patients [57, 58]. Interferon- $\gamma$ also has hematopoiesis-suppressive properties and is elevated in various acquired marrow failure syndromes including MDS [59]. Interferon regulatory factor- 1 is a transcription co-activator involved in interferon signaling and acts as a tumor suppressor. In one report, patients with MDS and an associated AIC had high rates of interferon regulatory factor-1 expression as compared to patients with MDS without an AIC [60]. TGF- $\beta$, a myelosuppressive cytokine, and its downstream effectors have recently been shown to be significant players in erythropoietin-resistant anemia in MDS. Various pathway inhibitors are currently in early clinical trials and show promising results [61-64]. The aberrant cytokine profile in MDS can be viewed both as the cause for and a consequence of MDS pathophysiology.

Genetics in MDS can affect disease phenotype. For example, SF3B1 mutations are associated with refractory anemia with ring sideroblasts, mutations in the ATRX 
gene can result in an $\alpha$-thalassemia-like phenotype, and EZH2 loss-of-function mutations cause a chemotactic defect in neutrophils [65-67]. Whether specific mutations can predict autoimmune or inflammatory complications in MDS remains to be seen. One interesting association in that regard is that of trisomy 8 and AICs, specifically Behcet's syndrome - a systemic inflammatory vasculitis [68]. In one study, a statistically significant association was found between trisomy 8 and Behçet-like syndrome (trisomy 8 found in $4 / 6$ patients with Behçet's disease and in 4/79 patients with other AICs; $\mathrm{p}=0.003$ ) [8]. Interestingly, patients with constitutional trisomy 8 also seem to be at risk for Behçet-like manifestations [69].

Trisomy 8 is associated with significant CD8+ T-cell expansions which preferentially suppresses hematopoietic cell growth [70]. Trisomy 8 is also associated with overexpression of Wilms' tumor 1. T-cell immune responses to this antigen suggest a role for Wilms' tumor 1 in triggering $\mathrm{T}$-cell-mediated immune suppression in MDS [71]. Furthermore, Sloand et al. [70] studied 34 patients with MDS and trisomy 8 , and showed that two thirds of the patients who presented with trisomy 8 as their sole cytogenetic abnormality responded to IST.

Insights from aplastic anemia, a related acquired bone marrow failure syndrome suggest that different somatic mutations are associated with different immune responses. In a recent study, somatic mutations were found in one third of 439 patients with aplastic anemia. Mutations in BCOR and PIGA were the most frequent mutations found, and were associated with better response to IST and improved outcome [72]. Whether the outgrowth of mutant clones in the context of a specific T-cell-mediated autoimmune attack is due to immunoevasive properties conferred by these mutations and/or a proliferative advantage is unknown.

\section{Conclusion}

AICs are commonly encountered in the newly diagnosed or advanced MDS patient. In general, these complications do not seem to confer worse survival, although certain AICs may be associated with adverse outcome (e.g. vasculitis) or progression of MDS (Sweet's syndrome). Nonetheless, these complications may have a significant impact on quality of life and affect the timing and type of MDS-directed therapy. The mainstay of management of these complications in the short term relies on IST, but increasing evidence suggests that MDS-directed therapy, mainly HMAs, may be effective in treating these complications and reduce steroid doses. While the pathogenesis of AICs is incompletely understood, growing appreciation of cellular immune deregulation, cytokine hypersecretion, and the genetic heterogeneity underlying MDS may improve our understanding of common pathways linking MDS, inflammation, and autoimmunity.

\section{Disclosure Statement}

The authors report no conflicts of interests or funding sources.

\section{References}

1 Bejar R, Steensma DP: Recent developments in myelodysplastic syndromes. Blood 2014; 124:2793-2803.

2 Anderson LA, Pfeiffer RM, Landgren O, Gadalla S, Berndt SI, Engels EA: Risks of myeloid malignancies in patients with autoimmune conditions. Br J Cancer 2009;100:822828.

3 Kristinsson SY, Björkholm M, Hultcrantz M, Derolf ÅR, Landgren O, Goldin LR: Chronic immune stimulation might act as a trigger for the development of acute myeloid leukemia or myelodysplastic syndromes. J Clin Oncol 2011;29:2897-2903.

4 Wilson AB, Neogi T, Prout M, Jick S: Relative risk of myelodysplastic syndromes in patients with autoimmune disorders in the general practice research database. Cancer Epidemiol 2014;38:544-549.
5 Enright H, Jacob HS, Vercellotti G, Howe R, Belzer M, Miller W: Paraneoplastic autoimmune phenomena in patients with myelodysplastic syndromes: response to immunosuppressive therapy. Br J Haematol 1995;91:403408.

6 Kwong YL: Azathioprine: association with therapy-related myelodysplastic syndrome and acute myeloid leukemia. J Rheumatol 2010;37:485-490.

7 Rosenthal NS, Farhi DC: Myelodysplastic syndromes and acute myeloid leukemia in connective tissue disease after single-agent chemotherapy. Am J Clin Pathol 1996;106: 676-679.
8 Mekinian A, Grignano E, Braun T, Decaux O, Liozon E, Costedoat-Chalumeau N, Kahn JE, Hamidou M, Park S, Puéchal X, Toussirot E, Falgarone G, Launay D, Morel N, Trouiller S, Mathian A, Gombert B, Schoindre Y, Lioger B, De Wazieres B, Amoura Z, Buchdaul AL, Georgin-Lavialle S, Dion J, Madaule S, Raffray L, Cathebras P, Piette JC, Rose C, Ziza JM, Lortholary O, Montestruc F, Omouri M, Denis $G$, Rossignol J, Nimubona $S$, Adès L, Gardin C, Fenaux P, Fain O: Systemic inflammatory and autoimmune manifestations associated with myelodysplastic syndromes and chronic myelomonocytic leukaemia: a French multicentre retrospective study. Rheumatology (Oxford) 2016;55:291-300. 
9 Mekinian A, Braun T, Decaux O, Falgarone G, Toussirot E, Raffray L, Omouri M, Gombert B, De Wazieres B, Buchdaul AL, Ziza JM, Launay D, Denis G, Madaule S, Rose C, Grignano E, Fenaux P, Fain O: Inflammatory arthritis in patients with myelodysplastic syndromes: a multicenter retrospective study and literature review of 68 cases. Medicine (Baltimore) 2014;93:1-10.

10 Al Ustwani O, Ford LA, Sait SJ, Block AM, Barcos M, Vigil CE, Griffiths EA, Thompson JE, Wang ES, Ambrus J Jr, Wetzler M: Myelodysplastic syndromes and autoimmune diseases - case series and review of literature. Leuk Res 2013;37:894-899.

11 Fain O, Hamidou M, Cacoub P, Godeau B, Wechsler B, Pariès J, Stirnemann J, Morin AS, Gatfosse M, Hanslik T, Belmatoug N, Blétry O, Cevallos R, Delevaux I, Fisher E, Hayem G, Kaplan G, Le Hello C, Mouthon L, Larroche C, Lemaire V, Piette AM, Piette JC, Ponge T, Puéchal X, Rossert J, Sarrot-Reynauld F, Sicard D, Ziza JM, Kahn MF, Guillevin L: Vasculitides associated with malignancies: analysis of sixty patients. Arthritis Rheum 2007;57: 1473-1480.

12 Komrokji RS, Kulasekararaj A, Al Ali NH, Kordasti S, Bart-Smith E, Craig BM, Padron E, Zhang L, Lancet JE, Pinilla-Ibarz J, List AF, Mufti GJ, Epling-Burnette PK: Autoimmune diseases and myelodysplastic syndromes. Am J Hematol 2016;91:E280-283.

13 Hamidou MA, Boumalassa A, Larroche C, El Kouri D, Blétry O, Grolleau JY: Systemic medium-sized vessel vasculitis associated with chronic myelomonocytic leukemia. Semin Arthritis Rheum 2001;31:119-126.

14 Kawabata H, Sawaki T, Kawanami T, Shimoyama K, Karasawa H, Fukushima T, Masaki Y, Ogawa N, Hirose Y, Ozaki K, Shimanaka $\mathrm{K}$, Takase $\mathrm{S}$, Ueno $\mathrm{H}$, Umehara $\mathrm{H}$ : Myelodysplastic syndrome complicated with inflammatory intestinal ulcers: significance of trisomy 8. Intern Med 2006;45:1309-1314.

15 Tada Y, Koarada S, Haruta Y, Mitamura M, Ohta A, Nagasawa K: The association of Behçet's disease with myelodysplastic syndrome in Japan: a review of the literature. Clin Exp Rheumatol 2006;24:S115-S119.

16 Soppi E, Nousiainen T, Seppa A, Lahtinen R: Acute febrile neutrophilic dermatosis (Sweet's syndrome) in association with myelodysplastic syndromes: a report of three cases and a review of the literature. Br J Haematol 1989; 73:43-47.

17 Billström R, Johansson H, Johansson B, Mitelman F: Immune-mediated complications in patients with myelodysplastic syndromes - clinical and cytogenetic features. Eur J Haematol 1995;55:42-48.

18 Giannouli S, Voulgarelis M, Zintzaras E, Tzioufas AG, Moutsopoulos HM: Autoimmune phenomena in myelodysplastic syndromes: a 4 -yr prospective study. Rheumatology (Oxford) $2004 ; 43: 626-632$.
19 Dalamaga M, Karmaniolas K, Matekovits A, Migdalis I, Papadavid E: Cutaneous manifestations in relation to immunologic parameters in a cohort of primary myelodysplastic syndrome patients. J Eur Acad Dermatol Venereol 2008;22:543-548.

20 de Hollanda A, Beucher A, Henrion D, Ghali A, Lavigne C, Lévesque $H$, Hamidou M, Subra JF, Ifrah N, Belizna C: Systemic and immune manifestations in myelodysplasia: a multicenter retrospective study. Arthritis Care Res (Hoboken) 2011;63:1188-1194.

21 Marisavljević D, Kraguljac N, Rolović Z: Immunologic abnormalities in myelodysplastic syndromes: clinical features and characteristics of the lymphoid population. Med Oncol 2006;23:385-391.

22 Okamoto T, Okada M, Mori A, Saheki K, Takatsuka H, Wada H, Tamura A, Fujimori Y, Takemoto Y, Kanamaru A, Kakishita E: Correlation between immunological abnormalities and prognosis in myelodysplastic syndrome patients. Int J Hematol 1997;66: 345-351.

23 Frietsch JJ, Dornaus S, Neumann T, Scholl S, Schmidt V, Kunert C, Sayer HG, Hochhaus A, La Rosée P: Paraneoplastic inflammation in myelodysplastic syndrome or bone marrow failure: case series with focus on 5-azacytidine and literature review. Eur J Haematol 2014; 93:247-259.

24 Azar L, Khasnis A: Paraneoplastic rheumatologic syndromes. Curr Opin Rheumatol 2013; 25:44-49.

25 Pilorge S, Doleris LM, Dreyfus F, Park S: The autoimmune manifestations associated with myelodysplastic syndrome respond to 5-azacytidine: a report on three cases. Br J Haematol 2011;153:664-665.

26 Raj K, Ho A, Creamer JD, du Vivier AW, Salisbury JR, Mufti GJ: Complete response of deep neutrophilic dermatosis associated with myelodysplastic syndrome to 5-azacytidine. Br J Dermatol 2007;156:1039-1041.

27 Al Ustwani O, Francis J, Wallace PK, Ambrus J Jr, Wetzler M: Treating myelodysplastic syndrome improves an accompanying autoimmune disease along with a reduction in regulatory T-cells. Leuk Res 2011;35:e35-e36.

28 Fraison JB, Mekinian A, Grignano E, Kahn JE, Arlet JB, Decaux O, Denis G, Buchdahl AL, Omouri M, Maigne G, Aouba A, Leon N, Berthier S, Liozon E, Park S, Gardin C, Lortholary O, Rossignol J, Fenaux P, Fain O, Braun T: Efficacy of azacitidine in autoimmune and inflammatory disorders associated with myelodysplastic syndromes and chronic myelomonocytic leukemia. Leuk Res 2016;43: 13-17.

29 Bejar R, Stevenson K, Abdel-Wahab O, Galili N, Nilsson B, Garcia-Manero G, Kantarjian H, Raza A, Levine RL, Neuberg D, Ebert BL: Clinical effect of point mutations in myelodysplastic syndromes. N Engl J Med 2011;364: 2496-2506.
30 Haferlach T, Nagata Y, Grossmann V, Okuno Y, Bacher U, Nagae G, Schnittger S, Sanada M, Kon A, Alpermann T, Yoshida K, Roller A, Nadarajah N, Shiraishi Y, Shiozawa Y, Chiba K, Tanaka H, Koeffler HP, Klein HU, Dugas M, Aburatani H, Kohlmann A, Miyano S, Haferlach C, Kern W, Ogawa S: Landscape of genetic lesions in 944 patients with myelodysplastic syndromes. Leukemia 2014;28:241247.

31 Papaemmanuil E, Gerstung M, Malcovati L, Tauro S, Gundem G, Van Loo P, Yoon CJ, Ellis $\mathrm{P}$, Wedge DC, Pellagatti A, Shlien A, Groves MJ, Forbes SA, Raine K, Hinton J, Mudie LJ, McLaren S, Hardy C, Latimer C, Della Porta MG, O’Meara S, Ambaglio I, Galli A, Butler AP, Walldin G, Teague JW, Quek L, Sternberg A, Gambacorti-Passerini C, Cross NC, Green AR, Boultwood J, Vyas P, Hellstrom-Lindberg E, Bowen D, Cazzola M, Stratton MR, Campbell PJ: Clinical and biological implications of driver mutations in myelodysplastic syndromes. Blood 2013;122: 3616-3627; quiz 3699.

32 Lim ZY, Killick S, Germing U, Cavenagh J, Culligan D, Bacigalupo A, Marsh J, Mufti GJ: Low IPSS score and bone marrow hypocellularity in MDS patients predict hematological responses to antithymocyte globulin. Leukemia 2007;21:1436-1441.

33 Sloand EM, Olnes MJ, Shenoy A, Weinstein $\mathrm{B}$, Boss $\mathrm{C}$, Loeliger $\mathrm{K}$, Wu CO, More K, Barrett AJ, Scheinberg P, Young NS: Alemtuzumab treatment of intermediate-1 myelodysplasia patients is associated with sustained improvement in blood counts and cytogenetic remissions. J Clin Oncol 2010;28:51665173.

34 Fozza C, Contini S, Galleu A, Simula MP, Virdis P, Bonfigli S, Longinotti M: Patients with myelodysplastic syndromes display several $\mathrm{T}$ cell expansions, which are mostly polyclonal in the $\mathrm{CD} 4^{+}$subset and oligoclonal in the $\mathrm{CD}^{+}$subset. Exp Hematol 2009;37:947-955.

35 Fozza C, Longinotti M: The role of T-cells in the pathogenesis of myelodysplastic syndromes: passengers and drivers. Leuk Res 2013;37:201-203.

36 Epling-Burnette PK, Painter JS, Rollison DE, Ku E, Vendron D, Widen R, Boulware D, Zou JX, Bai F, List AF: Prevalence and clinical association of clonal T-cell expansions in myelodysplastic syndrome. Leukemia 2007;21: 659-667.

37 Vercauteren SM, Starczynowski DT, Sung S, McNeil K, Salski C, Jensen CL, Bruyere H, Lam WL, Karsan A: T cells of patients with myelodysplastic syndrome are frequently derived from the malignant clone. $\mathrm{Br} \mathrm{J}$ Haematol 2012;156:409-412.

38 Baumann I, Scheid C, Koref MS, Swindell R, Stern P, Testa NG: Autologous lymphocytes inhibit hemopoiesis in long-term culture in patients with myelodysplastic syndrome. Exp Hematol 2002;30:1405-1411. 
39 Yang L, Eksioglu EA, Wei S: hTERT deficiency in naive T cells affects lymphocyte homeostasis in myelodysplastic syndrome patients. Oncoimmunology 2013;2:e26329.

40 Mailloux AW, Young MR: Regulatory T-cell trafficking: from thymic development to tumor-induced immune suppression. Crit Rev Immunol 2010;30:435-447.

41 Alfinito F, Sica M, Luciano L, Della Pepa R, Palladino C, Ferrara I, Giani U, Ruggiero G, Terrazzano G: Immune dysregulation and dyserythropoiesis in the myelodysplastic syndromes. Br J Haematol 2010;148:90-98.

42 Fozza C, Longu F, Contini S, Galleu A, Virdis P, Bonfigli S, Murineddu M, Gabbas A, Longinotti M: Patients with early-stage myelodysplastic syndromes show increased frequency of $\mathrm{CD} 4+\mathrm{CD} 25^{\text {high }}+\mathrm{CD} 127^{\text {low }}$ regulatory $\mathrm{T}$ cells. Acta Haematol 2012;128:178-182.

43 Kordasti SY, Ingram W, Hayden J, Darling D, Barber L, Afzali B, Lombardi G, Wlodarski MW, Maciejewski JP, Farzaneh F, Mufti GJ: CD4+CD25high Foxp3+ regulatory T cells in myelodysplastic syndrome (MDS). Blood 2007;110:847-850.

44 Kotsianidis I, Bouchliou I, Nakou E, Spanoudakis E, Margaritis D, Christophoridou AV, Anastasiades A, Tsigalou C, Bourikas G, Karadimitris A, Tsatalas C: Kinetics, function and bone marrow trafficking of CD4+CD25+Foxp3+ regulatory $\mathrm{T}$ cells in myelodysplastic syndromes (MDS). Leukemia 2009;23:510-518.

45 Mailloux AW, Sugimori C, Komrokji RS, Yang L, Maciejewski JP, Sekeres MA, Paquette R, Loughran TP Jr, List AF, EplingBurnette PK: Expansion of effector memory regulatory $\mathrm{T}$ cells represents a novel prognostic factor in lower risk myelodysplastic syndrome. J Immunol 2012;189:3198-3208.

46 Kordasti SY, Afzali B, Lim Z, Ingram W, Hayden J, Barber L, Matthews K, Chelliah R, Guinn B, Lombardi G, Farzaneh F, Mufti GJ: IL-17-producing $\mathrm{CD}^{+}{ }^{+} \mathrm{T}$ cells, pro-inflammatory cytokines and apoptosis are increased in low risk myelodysplastic syndrome. $\mathrm{Br} \mathrm{J}$ Haematol 2009;145:64-72.

47 Costantini B, Kordasti SY, Kulasekararaj AG, Jiang J, Seidl T, Abellan PP, Mohamedali A, Thomas NS, Farzaneh F, Mufti GJ: The effects of 5 -azacytidine on the function and number of regulatory T cells and T-effectors in myelodysplastic syndrome. Haematologica 2013; 98:1196-1205.

48 Fozza C, Corda G, Barraqueddu F, Virdis P, Contini S, Galleu A, Isoni A, Dore F, Angelucci E, Longinotti M: Azacitidine improves the T-cell repertoire in patients with myelodysplastic syndromes and acute myeloid leukemia with multilineage dysplasia. Leuk Res 2015;39:957-963.

49 Aggarwal S, van de Loosdrecht AA, Alhan C, Ossenkoppele GJ, Westers TM, Bontkes HJ: Role of immune responses in the pathogenesis of low-risk MDS and high-risk MDS: implications for immunotherapy. Br J Haematol 2011;153:568-581.
50 Sternberg A, Killick S, Littlewood T, Hatton C, Peniket A, Seidl T, Soneji S, Leach J, Bowen D, Chapman C, Standen G, Massey E, Robinson L, Vadher B, Kaczmarski R, Janmohammed R, Clipsham K, Carr A, Vyas P: Evidence for reduced B-cell progenitors in early (lowrisk) myelodysplastic syndrome. Blood 2005; 106:2982-2991.

51 Chen X, Eksioglu EA, Zhou J, Zhang L, Djeu J, Fortenbery N, Epling-Burnette P, Van Bijnen S, Dolstra H, Cannon J, Youn JI, Donatelli SS, Qin D, De Witte T, Tao J, Wang H, Cheng P, Gabrilovich DI, List A, Wei S: Induction of myelodysplasia by myeloid-derived suppressor cells. J Clin Invest 2013;123: 4595-4611.

52 Meirow Y, Kanterman J, Baniyash M: Paving the road to tumor development and spreading: myeloid-derived suppressor cells are ruling the fate. Front Immunol 2015;6:523.

53 Bachegowda L, Gligich O, Mantzaris I, Schinke C, Wyville D, Carrillo T, Braunschweig I, Steidl U, Verma A: Signal transduction inhibitors in treatment of myelodysplastic syndromes. J Hematol Oncol 2013;6:50.

54 Schwartz DM, Bonelli M, Gadina M, O'Shea JJ: Type I/II cytokines, JAKs, and new strategies for treating autoimmune diseases. Nat Rev Rheumatol 2016;12:25-36.

55 Claessens YE, Bouscary D, Dupont JM, Picard F, Melle J, Gisselbrecht S, Lacombe C, Dreyfus F, Mayeux P, Fontenay-Roupie M: In vitro proliferation and differentiation of erythroid progenitors from patients with myelodysplastic syndromes: evidence for Fas-dependent apoptosis. Blood 2002;99:1594-1601.

56 Maciejewski J, Selleri C, Anderson S, Young NS: Fas antigen expression on CD34+ human marrow cells is induced by interferon gamma and tumor necrosis factor alpha and potentiates cytokine-mediated hematopoietic suppression in vitro. Blood 1995;85:3183-3190.

57 Stasi R, Amadori S: Infliximab chimaeric antitumour necrosis factor alpha monoclonal antibody treatment for patients with myelodysplastic syndromes. Br J Haematol 2002;116: 334-337.

58 Stasi R, Amadori S, Newland AC, Provan D: Infliximab chimeric antitumor necrosis factor- $\alpha$ monoclonal antibody as potential treatment for myelodysplastic syndromes. Leuk Lymphoma 2005;46:509-516.

59 Zeng W, Miyazato A, Chen G, Kajigaya S, Young NS, Maciejewski JP: Interferon-gamma-induced gene expression in CD34 cells: identification of pathologic cytokine-specific signature profiles. Blood 2006;107:167-175.

60 Giannouli S, Tzoanopoulos D, Ritis K, Kartalis G, Moutsopoulos HM, Voulgarelis M: Autoimmune manifestations in human myelodysplasia: a positive correlation with interferon regulatory factor-1 (IRF-1) expression. Ann Rheum Dis 2004;63:578-582.
61 Platzbecker U, Al-Ali HK, Gattermann N, Haase D, Janzen V, Krauter J, Götze K, Schlenk R, Nolte F, Letsch A, Ottmann OG, Kündgen A, Lübbert M, Germing U, Wermke M, Reinhard H, Weiss C, Lieder K, Ehninger G, Leismann O, Giagounidis A: Phase 2 study of oral panobinostat (LBH589) with or without erythropoietin in heavily transfusion-dependent IPSS low or int-1 MDS patients. Leukemia 2014;28:696-698.

62 Suragani RN, Cadena SM, Cawley SM, Sako D, Mitchell D, Li R, Davies MV, Alexander MJ, Devine M, Loveday KS, Underwood KW, Grinberg AV, Quisel JD, Chopra R, Pearsall RS, Seehra J, Kumar R: Transforming growth factor- $\beta$ superfamily ligand trap ACE-536 corrects anemia by promoting late-stage erythropoiesis. Nat Med 2014;20:408-414.

63 Zhou L, McMahon C, Bhagat T, Alencar C, Yu Y, Fazzari M, Sohal D, Heuck C, Gundabolu K, Ng C, Mo Y, Shen W, Wickrema A, Kong G, Friedman E, Sokol L, Mantzaris I, Pellagatti A, Boultwood J, Platanias LC, Steidl U, Yan L, Yingling JM, Lahn MM, List A, Bitzer M, Verma A: Reduced SMAD7 leads to overactivation of TGF-beta signaling in MDS that can be reversed by a specific inhibitor of TGF-beta receptor I kinase. Cancer Res 2011; 71:955-963.

64 Zhou L, Nguyen AN, Sohal D, Ying Ma J, Pahanish P, Gundabolu K, Hayman J, Chubak A, Mo Y, Bhagat TD, Das B, Kapoun AM, Navas TA, Parmar S, Kambhampati S, Pellagatti A, Braunchweig I, Zhang Y, Wickrema A, Medicherla S, Boultwood J, Platanias LC, Higgins LS, List AF, Bitzer M, Verma A: Inhibition of the TGF-beta receptor I kinase promotes hematopoiesis in MDS. Blood 2008; 112:3434-3443.

65 Malcovati L, Karimi M, Papaemmanuil E, Ambaglio I, Jädersten M, Jansson M, Elena C, Gallì A, Walldin G, Della Porta MG, Raaschou-Jensen K, Travaglino E, Kallenbach K, Pietra D, Ljungström V, Conte S, Boveri E, Invernizzi R, Rosenquist R, Campbell PJ, Cazzola M, Hellström Lindberg E: SF3B1 mutation identifies a distinct subset of myelodysplastic syndrome with ring sideroblasts. Blood 2015;126:233-241.

66 Steensma DP, Gibbons RJ, Higgs DR: Acquired alpha-thalassemia in association with myelodysplastic syndrome and other hematologic malignancies. Blood 2005; 105:443452 .

67 Caughey B, Xie H, Orkin SH, Sykes DB, Ebert BL, Bejar R: Functional defects in neutrophils derived from Ezh2 null mice [abstract]. Blood 122(21); 1556.

68 Kimura S, Kuroda J, Akaogi T, Hayashi H, Kobayashi Y, Kondo M: Trisomy 8 involved in myelodysplastic syndromes as a risk factor for intestinal ulcers and thrombosis - Behçet's syndrome. Leuk Lymphoma 2001;42:115121. 
69 Becker K, Fitzgerald O, Green AJ, Keogan M, Newbury-Ecob R, Greenhalgh L, Withers S, Hollox EJ, Aldred PM, Armour JA: Constitutional trisomy 8 and Behçet syndrome. Am J Med Genet A 2009;149A:982-986.

70 Sloand EM, Mainwaring L, Fuhrer M, Ramkissoon S, Risitano AM, Keyvanafar K, Lu J, Basu A, Barrett AJ, Young NS: Preferential suppression of trisomy 8 compared with normal hematopoietic cell growth by autologous lymphocytes in patients with trisomy 8 myelodysplastic syndrome. Blood 2005;106:841-851.
71 Sloand EM, Melenhorst JJ, Tucker ZC, Pfannes L, Brenchley JM, Yong A, Visconte V, Wu C, Gostick E, Scheinberg P, Olnes MJ, Douek DC, Price DA, Barrett AJ, Young NS: T-cell immune responses to Wilms tumor 1 protein in myelodysplasia responsive to immunosuppressive therapy. Blood 2011;117: 2691-2699.

72 Yoshizato T, Dumitriu B, Hosokawa K, Makishima H, Yoshida K, Townsley D, SatoOtsubo A, Sato Y, Liu D, Suzuki H, Wu CO, Shiraishi Y, Clemente MJ, Kataoka K, Shio- zawa Y, Okuno Y, Chiba K, Tanaka H, Nagata Y, Katagiri T, Kon A, Sanada M, Scheinberg P, Miyano S, Maciejewski JP, Nakao S, Young NS, Ogawa S: Somatic mutations and clonal hematopoiesis in aplastic anemia. $\mathrm{N}$ Engl J Med 2015;373:35-47.

73 Hamidou MA, Derenne S, Audrain MA, Berthelot JM, Boumalassa A, Grolleau JY: Prevalence of rheumatic manifestations and antineutrophil cytoplasmic antibodies in haematological malignancies. A prospective study. Rheumatology (Oxford) 2000;39:417-420. 